\title{
Authentic Texts and Pakistani Learners' ESL Reading Comprehension Skills: A Mixed-Method Study
}

\author{
Asma Aftab \\ Kinnaird College for Women, Lahore, Pakistan \\ Afsheen Salahuddin \\ Kinnaird College for Women, Lahore, Pakistan
}

\begin{abstract}
This paper highlights the varied perspectives towards authenticity and discusses a study which investigated the effects of utilizing authentic texts instead of the traditionally used passages on the Grades VI and VII students in an Asian ESL context, namely Pakistan. The research adopted a mixed method approach incorporating an experimental design and semi-structured questionnaires and involved 154 students of two private schools. The results showed that the reading comprehension abilities of more proficient and average learners who were exposed to authentic texts improved significantly as compared to the abilities of those who only had exposure to the traditional textbook material. The questionnaire responses indicated that the students were interested in reading authentic texts and they wanted these texts incorporated in their syllabus. Thus it is proposed that authentic texts should be utilized in second language classrooms, which can lead to the development of more proficient readers.
\end{abstract}

The theoretical beliefs underpinning the concept of authenticity in relation to language teaching have been undergoing considerable perceptional shifts in the last few decades which call for further investigations in actual educational environments. Initially, authenticity was only linked to texts which were taken from the world outside the classroom; thereafter with the importance being placed on language activities and learners, the scope of authenticity was extended to include varied aspects of the educational environment (Joy, 2011; Mishan, 2004). However, these changes in points of view also tended to obscure the concept. At the same time, a section of the literature (e.g., Berardo, 2006) continued to emphasize the importance of authentic texts in the acquisition of reading comprehension skills but without decisive evidence in support of the co-relation. Thus this article, while discussing the theoretical beliefs related to authentic texts, importantly presents a small scale study which attempted to provide empirical evidence indicating the positive influence of these text types on the second language reading comprehension skills of Pakistani learners.

In Pakistan, English is the second language which is being utilized in the major spheres of power, such as bureaucracy, commerce, and education (Pinon \& Haydon, 2010).

Nevertheless, the authors have assessed that the English reading skills of their college level

Language Education in Asia, 2015, 6(2), 122-134. http://dx.doi.org/10.5746/LEiA/15/V6/I2/A4/Aftab_Salahuddin 
Pakistani students are inadequate because the learners have difficulty understanding the English material taken from the real world, though they may be able to handle typical classroom reading tasks. These deficiencies could be linked to inadequate teaching techniques and, specifically, the prescribed English textbooks, most of which incorporate non-authentic texts (Aftab, 2011) which can limit the learners' abilities to only handling these kinds of texts. Thus this study investigated the degree authentic texts can help Pakistani Grade VI and VII level students improve their ESL reading comprehension skills and whether the learners are motivated to read these texts.

The opening sections of this article will attempt to define "reading" and authenticity, and encapsulate a few studies focusing on the impact of authentic material on reading. The second part of the article will focus on the study: its research methodology, results, and implications.

\section{What is Reading?}

\section{Literature Review}

Reading is believed to be "interactive" in two respects. First, reading involves different processes (e.g., decoding, inference, prediction, and monitoring) taking place "simultaneously" and secondly, it entails interaction of "linguistic information" with knowledge from "long term memory" and schema (Grabe \& Stoller, 2011, pp. 11-12). Snow and Sweet (2003) have defined reading comprehension as "the process of simultaneously extracting and constructing meaning through interaction and involvement with written language" (p. 10). These assumptions emphasize that reading is interaction whether external between the reader and the text or internal involving cognitive processes. Second language reading comprehension also involves interacting with the text, but the process may be rendered difficult in many instances because of unfamiliar cultural schemata and lexis (Iwai, 2010).

\section{The Plurality of "Authenticity" in Language Learning}

Authentic texts have been defined from diverse theoretical angles. According to Morrow (1977, p. 13), "an authentic text is one written for the purpose of communicating information (not of illustrating specific language points)." Some sections of literature (e.g., Thornbury, 2006) adopting Morrow's (1977) line of argument have asserted that authentic texts are those materials which have not been especially prepared for language learning. The implications elicited from these definitions of authentic text can be summarized as follows: this type of text gives "exposure to real language and its use in its own community" (Widdowson, 1990, as cited in Tamo, 2009, p. 75). However, other sections of the literature have indicated limitations inherent in the concept of authenticity in relation to language teaching. For instance, Joy (2011) stated that the term authentic text is too open-ended to promote application in educational contexts.

In fact, learners' own reactions are more important than the kinds of utilized texts as far as language acquisition is concerned, and if a text (irrespective of its nature) is employed to help learners use the language in the classroom, this kind of practice can be equated with authenticity (Joy, 2011). Nevertheless, to create authentic language use scenarios in classrooms, the trend is to employ simulations which are by their very nature unreal. For example, if an activity requires the students to complete a bank form, the used text (a form) is real, but the created location (a bank) and the roles assigned to the students (individuals asking for a bank draft) are artificial since the classroom is not a bank and the individuals are language learners (Joy, 2011). This example reflects the unstable nature of the authentic text concept and thus Joy (2011) claimed that the purpose behind using the text should be the criteria for determining authenticity in the language classroom. Similarly, Mishan (2004) asserted that an 
authentic text is something unique and limited to a particular context. In this sense, the issue of authentic text is complex. In contrast, the relation of authenticity to language use is relatively more straightforward: the activities generated by texts as viewed by users as having "real-life communicative" aims can be considered "authentic" (Mishan, 2004, p. 17). In fact, these multifaceted underpinnings associated with authenticity have led some linguists (notably Guariento \& Morley, 2001, and Joy, 2011) to classify the term into different categories. These categories look beyond authentic texts and incorporate other aspects of the learning environment such as activities, learners' responses, and classroom situations (Shomoossi \& Ketabi, 2007).

Notwithstanding the plurality of meanings associated with authenticity in relation to language learning and the importance of tasks and learners' perceptions, it is pertinent to highlight that students' views about educational aspects may not necessarily be valid or even relevant due to their own limited expectations, beliefs, and experiences in some educational contexts. For instance, some learners may favour or plainly accept mechanical activities (e.g., completing gapped sentences) or simplified texts as effective because these materials are cognitively less challenging or the learners are not aware of the diverse task / text types available, irrespective of whether these materials are relevant in the context and facilitate the acquisition of the target language or not. Furthermore, language activities are diverse and they display varied degrees of authenticity, and so the discussion of such a wide topic in the limited space of this article cannot possibly do justice to the subject. Thus further discussion related to authenticity in this paper will limit itself to authentic texts implying real language since the discussed study attempted to investigate the extent exposure to authentic reading texts in a second language educational scenario can lead to effective acquisition of the target language.

\section{Nature of Authentic Texts}

Non-authentic texts, which generally utilize "accurate" sentence constructions and "unreal" language, are apparently more suitable for teaching grammar rather than developing reading skills (Berardo, 2006, p. 62). In contrast, authentic material incorporates diverse sentence patterns, lexis, and other stylistic features aiming to present content using effective language relevant to the objectives of communication. The following examples of texts (taken from two English textbooks prescribed in Grade VI of Pakistani schools) illustrate these differences between authentic and non-authentic texts:

Text A

He watched them [the dolphins] stall and turn in perfect formation, cutting white slices through the skin of the water, curving back on themselves . . . Now that was desperately cool, no question. (Jones \& Mann, 2006, p. 286)

\section{Text B}

After wandering for some time, I ate some more food I had with me and fell asleep. I had just begun to doze when a noise woke me up. (Howe, 2007, p. 159)

Text A is authentic; it is an excerpt of a children's novel (incorporated in the textbook) which has the communicative purpose of providing entertainment or aesthetic pleasure. Thus, varied sentence structures and effective and graphic lexis ("perfect," "cutting white slices," and "desperately cool" [Jones \& Mann, 2006, p. 286]) are appropriate here and mark this text as having what can be called a personal style. Moreover, this text also reflects the views of the writer about the dolphins capering in and out of the water. Text B, which is non-authentic, has the sole aim of assessing students' reading comprehension; it narrates events using similar 
sentence patterns without any vivid and descriptive details.

The literature (e.g., Tomlinson, 2008) has highlighted that the use of authentic texts have many advantages. For instance, exposure to authentic texts enhances the students' motivation because it provides opportunities for reading realistic language that is written for varied personal and professional reasons rather than only to present language for teaching purposes (Guariento \& Morley, 2001; Tamo, 2009). However, utilizing authentic texts within the classroom can also be problematic. For example, some of these materials can be culturally unfamiliar; the linguistic diversity and complexity of the text can also hinder decoding, leading to incomprehensibility; and using authentic materials in the classroom will require more preparation time for teachers (Berardo, 2006). Some of these limitations can be countered if the selected texts are compatible with the students' tastes, needs, and linguistic backgrounds (Berardo, 2006). Guariento and Morley (2001, p. 348) have suggested that reading activities should not require learners to understand each and every word (a technique known as "partial comprehension") since even in real life we do not necessarily try to comprehend the complete text all the time.

\section{Previous Studies}

The previous section listed a number of benefits of authentic texts as cited in literature; however, it is also important to examine empirical evidence of these assumptions through actual classroom-based studies. Konstantinos and Jeppe (2005) carried out a study in Swedish upper secondary schools to evaluate the attitudes of English students and one teacher towards authentic texts. The questionnaire and interview results showed that both the students and the teacher wanted to read authentic materials since these were based on appealing themes. The teacher also favoured authentic material as a means to create an active classroom and expose students to the real world language, but at the same time he indicated that to completely eliminate non-authentic texts was unrealistic. Therefore, a combination of the two types of texts should be utilized while teaching reading skills. Subsequently, Guo (2012) conducted an experimental study investigating the influence of extensive reading of authentic material on language competence of 49 Taiwanese college learners. The research illustrated improved vocabulary development and motivation. Ihtiari, Sundari, and Andayani (2013) through an Indonesian study, highlighted the positive effect of authentic texts on the English reading comprehension abilities of 100 Grade VIII learners. Finally, an experimental study (Marzban \& Davaji, 2015) illustrated the positive correlation between authentic texts use and reading comprehension of intermediate level EFL Iranian students; the research also highlighted that the motivational level of students incorporating aspects such as reading curiosity improved. However, the study was limited in utilizing a small number of respondents (24), and the groups were "homogeneous" (p. 90).

\section{The Current Study}

The studies discussed above have shown the positive influence of authentic texts on EFL reading skills and highlight the need for directly investigating the issue in a different language use scenario, namely ESL. Thus this article discusses a study examining the degree of effectiveness of authentic texts in a specific ESL context, namely two urban-based Pakistani private schools. This project shared some similarities with the above studies such as investigating the same co-relation, focusing on almost the same level of learners as those utilized in the Swedish, Indonesian, and Iranian studies (i.e., Grades VI and VII), and adopting primarily an experimental design like the abovementioned Asian projects. However, a relatively higher number of participants (154 students) were involved and a mixed-method based questionnaire survey was additionally incorporated. The current study is important since 
it can suggest the kinds of texts (specifically authentic or non-authentic material) that can help both develop effective reading skills and provide learners with a more motivating experience, leading to improvements in reading programmes in Asian second language learning settings.

The study was based on the following research questions (derived from the discussed literature):

1. To what extent can authentic texts help Pakistani middle level private sector students improve their ESL reading comprehension skills?

2. To what extent are the Pakistani ESL learners motivated to read authentic texts?

\section{Research Methodology}

The present research adopted the mixed-method approach, which involves the use of both quantitative and qualitative techniques and data in a single study. The quantitative procedures comprised the employment of closed-ended items incorporated in the two questionnaires and the experiment, while the qualitative approach involved the use of open-ended items included in the questionnaires. Dörnyei has commended this practice of integrating both approaches since "words can be used to add meaning to numbers and numbers can be used to add precision to words" (2007, p. 45).

One hundred fifty-four Grade VI and VII students of two private sector schools of Pakistan participated in the study. The participants, aged between ten and thirteen years, were all girls, and they belonged to different social backgrounds.

This study involved three phases. During the first phase, 43 of the participants randomly selected from the total sample population were surveyed about their views regarding the classroom reading texts through questionnaires (Questionnaire A) written in English. Questionnaires can be used to extract the attitudinal position of the respondents (Dörnyei, 2007) as was attempted in this study. This research tool was used since specific information was needed from a large number of participants during this phase. Questionnaire A had 6 closed-ended items requiring the students to respond by selecting any one of the three options - "Yes," "To a certain extent," and "Not at all" - and one open-ended question (see Appendix A). Closed-ended items were included in the questionnaire since elicitation of precise data was required (Dörnyei, 2007); an open-ended question was additionally utilized because the study required the respondents to simultaneously express their views freely, leading to more "insightful data" (as asserted by Mackey \& Gass, 2005, p. 93).

The second phase consisted of an experiment. The objective of the second phase of the study was to investigate the extent the use of authentic material could positively affect the reading comprehension abilities of a group of learners, and thus an experimental design was adopted. Students were randomly allocated to the experimental and control groups, each group consisting of 77 members.

Two pretests (one for each grade level) based on reading comprehension were prepared by the amalgamation of different authentic texts: a web-based flight schedule and a local magazine article were incorporated in the Grade VI test; a recipe page consisting of three recipes and a local newspaper article were included in the Grade VII test. The total marks of each test incorporating short-answer questions were 20.

After the administration of the pretest, the control group was taught reading comprehension through the use of non-authentic textbook material, while the experimental group was exposed to different types of authentic texts (e.g., articles, menus, and letters). The lessons commenced with brainstorming sessions aiming to acquaint all the participants with the topic of the reading 
texts and familiarize only the experimental group members with the utilized genres. After this, the students of both groups read the texts and answered questions based on the texts. For each group, the lessons were conducted in addition to the regular classes with the permission of the administration; the 45-minute classes were taken five times a week for three weeks. Since class size, gender, teacher, the adopted methodology, and the length and number of lessons were similar for all groups, the influence of other possible variables was minimized. Following the completion of the treatment period, both groups were given a posttest which was the same as the pretest.

The last phase was once again a questionnaire survey (Questionnaire B) involving 41 participants randomly selected from the experimental group. Questionnaire B (in English) had two closed-ended items with the same options as Questionnaire A and one open-ended question.

After eliciting data from the experiment and the two surveys, the findings were correlated to determine whether the responses helped in explaining the quantitative differences in the scores of participants exposed to authentic texts and those who were exposed to non-authentic texts.

\section{Findings}

\section{Phase I}

The responses to Item 1 of Questionnaire A (focusing on the interest level of the textbook material) were generally mixed (see Table 1). The responses to Items 2 and 3 indicated the majority's favourable attitude towards their coursebook texts for improving their reading comprehension and general knowledge. Nevertheless, most of the students affirmed that the texts incorporated in their textbook are not similar to the real-world texts (Item 4). The responses to Items 5 and 6 highlighted that the majority liked to read about a variety of topics and read different authentic texts. Finally, for the last open-ended item (requiring the students to suggest some changes in their reading course) the respondents stated that they wanted to read some new kind of material and a wider variety of texts.

\section{Table 1}

\section{Questionnaire A Quantitative Data}

\begin{tabular}{|l|c|c|c|}
\hline \multicolumn{1}{|c|}{ Item } & Yes & $\begin{array}{c}\text { To a } \\
\text { certain } \\
\text { extent }\end{array}$ & $\begin{array}{c}\text { Not at } \\
\text { all }\end{array}$ \\
\hline $\begin{array}{l}\text { 1. Do you find the passages given in your text books for the reading } \\
\text { comprehension skills interesting? }\end{array}$ & $35 \%$ & $44 \%$ & $21 \%$ \\
\hline $\begin{array}{l}\text { 2. Do you think that the passages in your textbooks help to improve } \\
\text { your reading comprehension skills? }\end{array}$ & $65 \%$ & $23 \%$ & $12 \%$ \\
\hline 3. Do these passages help to improve your general knowledge? & $46.5 \%$ & $32.5 \%$ & $21 \%$ \\
\hline $\begin{array}{l}\text { 4. Are these reading passages similar to the texts that you come } \\
\text { across outside the classroom (in story books, newspapers, } \\
\text { magazines, encyclopedias, etc., and on the internet)? }\end{array}$ & $14 \%$ & $19 \%$ & $67 \%$ \\
\hline 5. Do you want to read texts based on a variety of topics? & $98 \%$ & $2 \%$ & 0 \\
\hline $\begin{array}{l}\text { 6. Do you want to read different text types (recipes, advertisements, } \\
\text { movie reviews, stories, poems, newspaper / magazine / web } \\
\text { articles, Facebook pages and so on) in your class? }\end{array}$ & $93 \%$ & $2 \%$ & $5 \%$ \\
\hline
\end{tabular}




\section{Phase II}

Figure 1 compares the pretest percentage scores of both groups. A large number of students of both groups did not do well in the pretest: $44 \%$ of the control group learners obtained less than $50 \%$ (referred to as below average marks), while $54.5 \%$ of the experimental group participants similarly obtained below average marks.

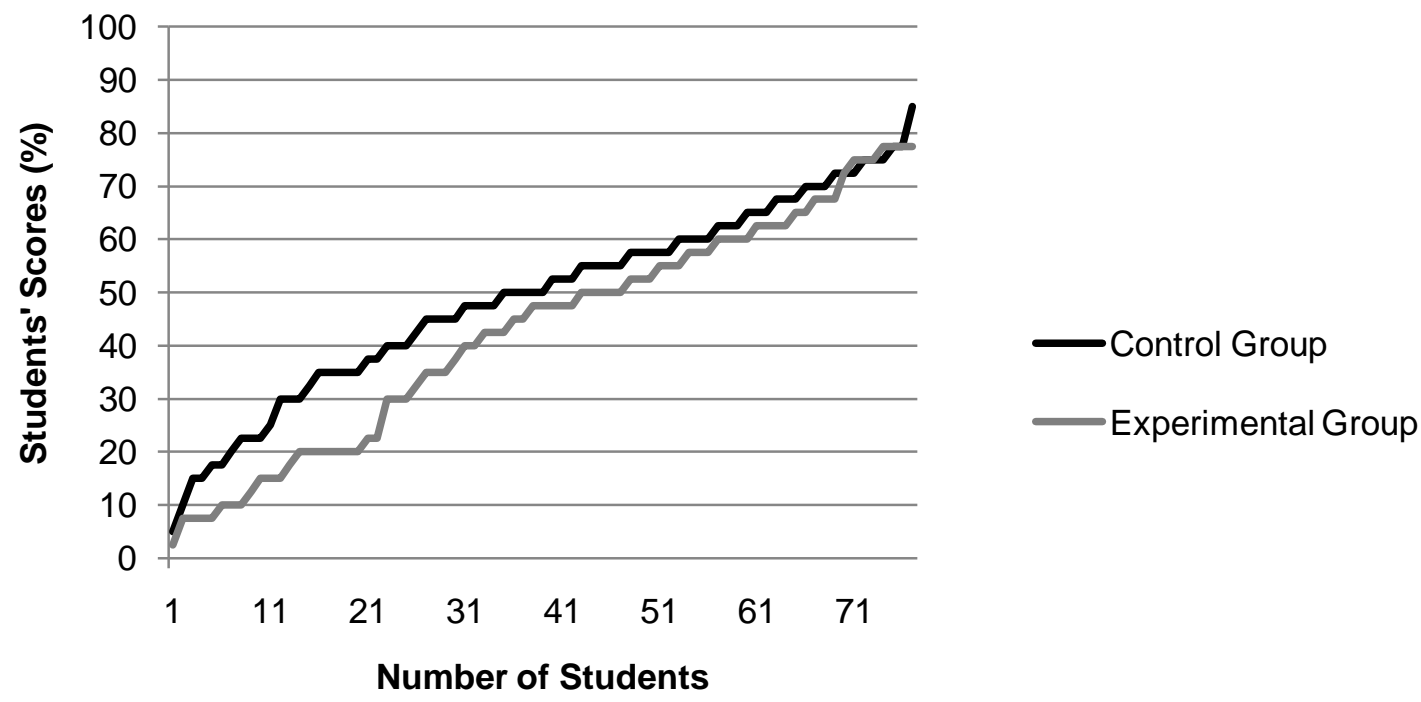

Figure 1. Control and experimental groups' pretest performance

Table 2 summarizes the key statistical data derived from the pretest. There seems to be little difference in the means obtained by the experimental and control groups. The very high standard deviations received by both groups indicate that their scores were very varied.

Table 2

Descriptive Statistical Analysis of the Pretest Data

\begin{tabular}{|c|c|c|}
\hline & Experimental Group & Control Group \\
\hline Mean & 42.825 & 49.156 \\
\hline SD & 21.496 & 18.343 \\
\hline
\end{tabular}

The results of the inferential statistical analysis of the pretest are presented in Table 3. The $p$ value is not less than 0.05 , and by standard criteria, this difference is considered to be not quite statistically significant.

\section{Table 3}

Inferential Statistical Analysis of the Pretest Data

\begin{tabular}{|c|c|}
\hline Difference in mean between the experimental and control groups & -6.331 \\
\hline $95 \%$ confidence interval of this difference & $-12.693-0.031$ \\
\hline standard error of difference & 3.220 \\
\hline$t$ & 1.9660 \\
\hline$p$ value & 0.0511 \\
\hline
\end{tabular}

Based on the scores and the statistical analysis, we can assume that both the groups were at almost the same level as far as the reading comprehension ability was concerned. One of the 
reasons for the poor performance of a large number of the participants in the two groups (see Figure 1) could be that no prior exposure to authentic texts was provided to the students in the classrooms.

Figure 2 compares the individual percentage scores obtained by the students of both groups in the posttest. Forty percent of the control group students scored below $50 \%$, while thirty percent of the experimental group learners were low achievers in this test.

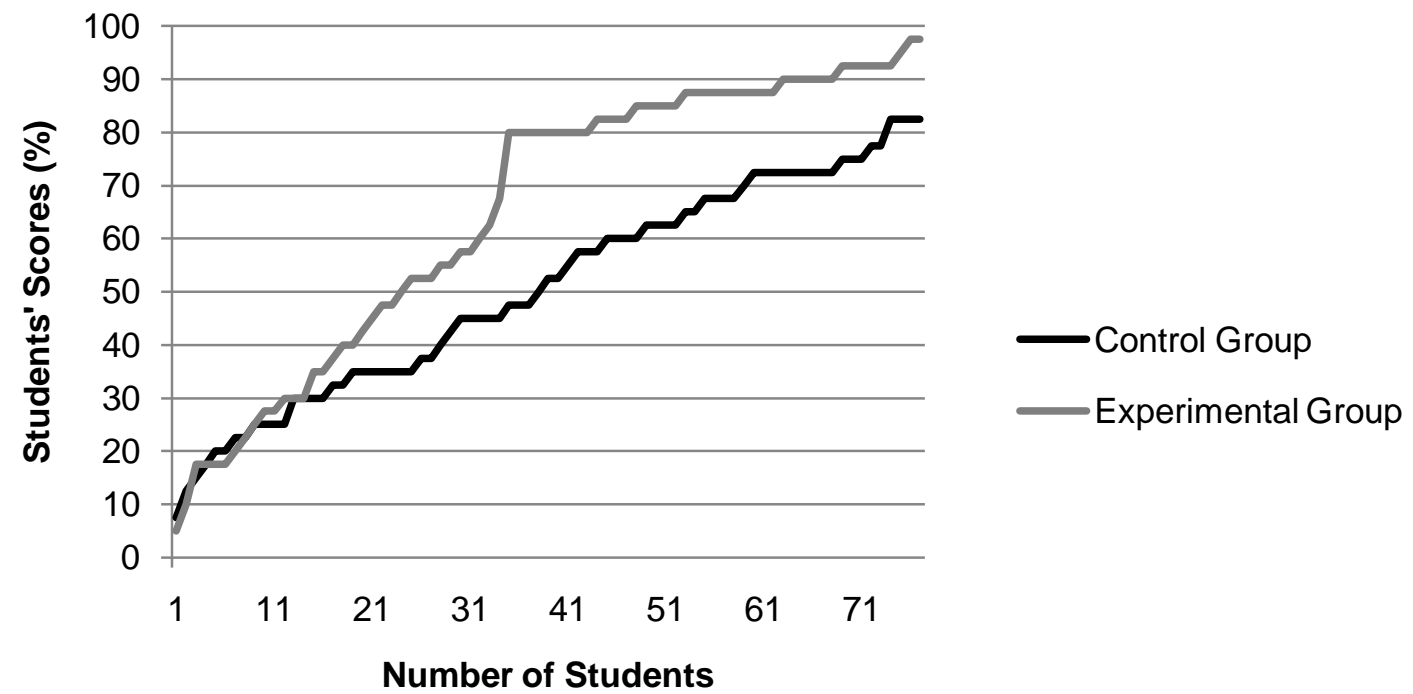

Figure 2. Control and experimental groups' posttest performance

Table 4 presents the descriptive statistical analysis of the posttest marks. Once again there was broad variance amongst the participants of each group as indicated by the extremely high standard deviations of each group. However, as the mean scores highlight, the experimental group performed better than the control group.

Table 4

Descriptive Statistical Analysis of the Posttest Data

\begin{tabular}{|c|c|c|}
\hline & Experimental Group & Control Group \\
\hline Mean & 65.260 & 50.617 \\
\hline SD & 27.034 & 20.246 \\
\hline
\end{tabular}

Table 5 presents the inferential statistical analysis of the posttest scores. The $p$ value is less than 0.05 in this case; by standard conventions, this difference is assumed to be extremely statistically significant.

Table 5

Inferential Statistical Analysis of the Posttest Data

\begin{tabular}{|c|c|}
\hline Difference in mean between the experimental and control groups & 14.643 \\
\hline $95 \%$ confidence interval of this difference & $7.038-22.247$ \\
\hline standard error of difference & 3.849 \\
\hline$t$ & 3.8043 \\
\hline$p$ value & 0.0002 \\
\hline
\end{tabular}


As can be seen in Figure 3, the difference in the performance of the control group in the pretest and posttest is minimal.

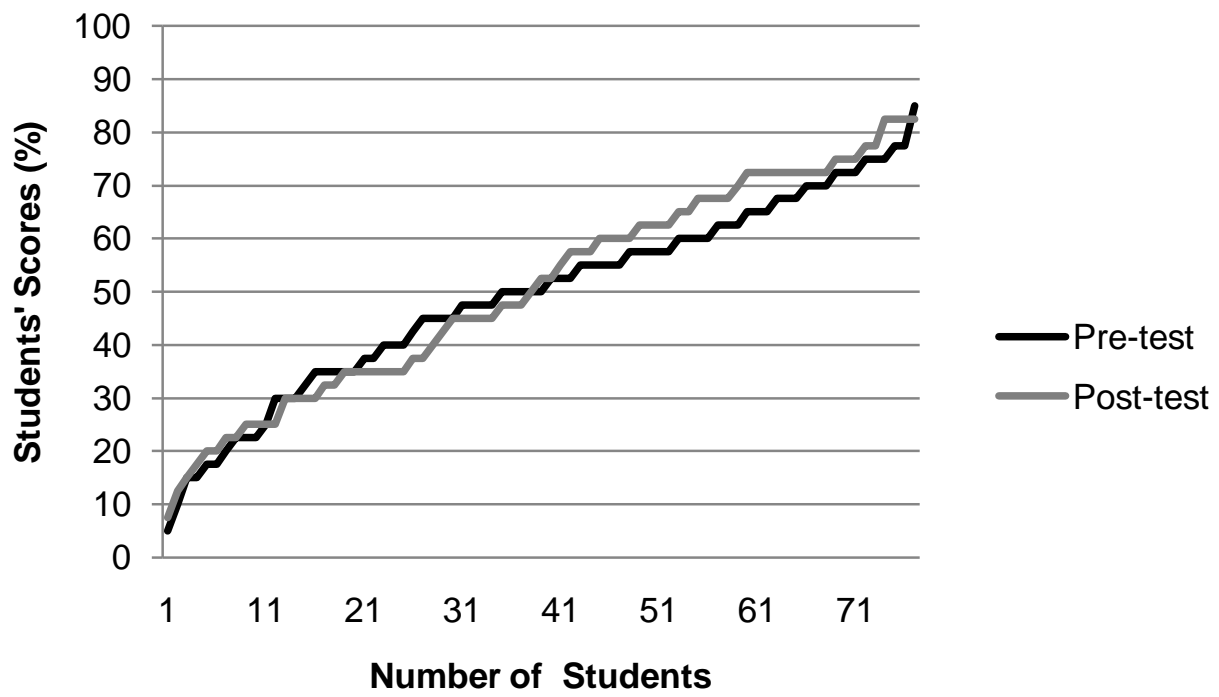

Figure 3. Control group pretest and posttest performance

However, as Figure 4 clearly highlights, the performance of the experimental group in the posttest significantly improved as compared to the group's performance in the pretest:

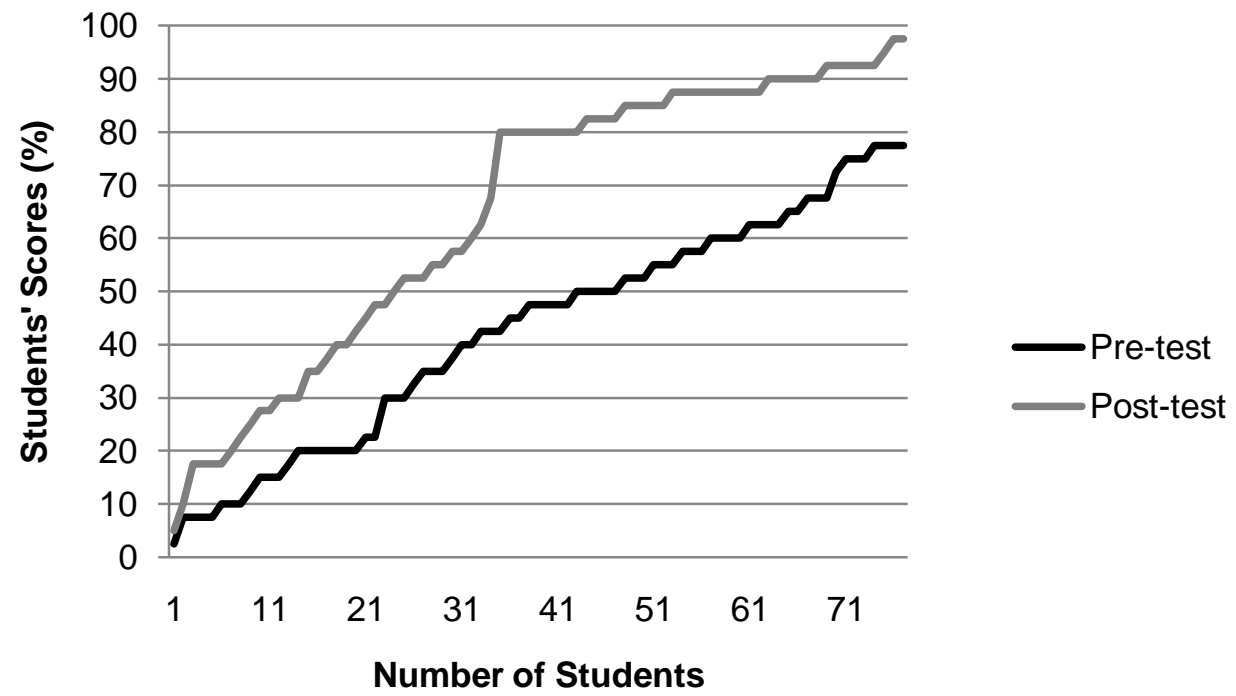

Figure 4. Experimental group pretest and posttest performance

\section{Phase III}

The responses to Items 1 and 3 of Questionnaire B (see Table 6) highlighted that most experimental group students enjoyed reading the provided authentic texts during the treatment period and perceived that these text types had helped them improve their reading skills. The second item required the students to provide reasons for their responses to the first item. Some respondents stated that they really liked the texts because these texts were different from those incorporated in their textbooks and they increased their knowledge, while others preferred the material since they were close to real life situations. The students further indicated that their 
syllabus was monotonous and that they wanted to have these text types included in their course.

Table 6

Questionnaire B Quantitative Data

\begin{tabular}{|l|c|c|c|}
\hline \multicolumn{1}{|c|}{ Item } & Yes & $\begin{array}{c}\text { To a } \\
\text { certain } \\
\text { extent }\end{array}$ & $\begin{array}{c}\text { Not at } \\
\text { all }\end{array}$ \\
\hline 1. Did you enjoy reading the texts that were given to you in class? & $78 \%$ & $22 \%$ & 0 \\
\hline $\begin{array}{l}\text { 3. How far do you feel that reading these texts and undertaking the } \\
\text { activities set on these texts have helped improve your reading } \\
\text { skills? }\end{array}$ & $85 \%$ & $15 \%$ & 0 \\
\hline
\end{tabular}

\section{Discussion}

The responses to the initial items of Questionnaire A survey highlighted that the majority of the respondents held a positive attitude towards their textbook reading texts. Apparently due to the students' limited vision, they believed that they were adequately informed about the world and that they had developed effective reading skills based on the good marks that they attained in routine classroom examinations. Nevertheless, as the learners were aware of the variety of reading texts available outside the class, most of the students realized that the coursebook texts were different from the reading material available outside the classroom. Most respondents wanted to study about a variety of topics and read different authentic texts. The reason behind these beliefs could be that the students were aware of these text types since they had come across these texts in their daily lives through the Internet, newspapers, and magazines, but this exposure had not been related to their classroom learning.

The data elicited from the experiment and presented highlight that the experimental group showed significant improvement in the posttest as far as their reading comprehension ability was concerned, while the control group did not show much improvement. The possible reason behind these findings seemed to be that the control group was not provided any exposure to the authentic texts during the treatment period, while the experimental group was trained through the exposure to these text types. The findings of the experiment additionally indicate that while among the control group members there did not seem any significant increase in number of students in the top slot (between $80 \%$ and 100\% marks) in the posttest, for the experimental group students, there was an increase from zero to 44 . However, the treatment seemed to have had no effect on the experimental group learners receiving the lowest scores. Thus it seemed that the treatment had more significant effect on the average and high achievers than the weakest students. However, it is possible that if the treatment had been provided for a period substantially longer than three weeks, the scores of some / most of the low achievers would have improved. At the same time, other factors which could be responsible for the poor reading comprehension ability of the weak students (e.g., weak decoding skills, inadequate vocabulary, and poor overall linguistic proficiency) cannot be ruled out.

The students' responses to the Questionnaire B survey items highlighted that the majority favoured the authentic material presented during the treatment. These responses, while providing further support to the findings elicited by Konstantinos and Jeppe's (2005) study, imply that exposure to authentic texts in class made the learners realize that there can be other types of material available for the development of reading skills in the classroom. Moreover, this study highlighted that the respondent students seemed motivated to read authentic texts, as has been illustrated by Guo (2012) through research, and claimed by Guariento and Morley 
(2001) and Tamo (2009). Thus it can be assumed that the use of authentic texts can be beneficial especially as far as reading comprehension skills and motivation to read are concerned for second language learners in other countries as well.

Though the data helped fulfill the research objectives, there were some limitations in the research design: the research was at only two private urban-based schools, and the treatment period was limited to three weeks. These shortcomings could have influenced the reliability and validity of the study.

\section{Conclusion}

The discussed study investigating the effect of authentic texts on Pakistani ESL students' reading skills highlighted the positive influence and the general favourable attitudes of the respondents towards these texts. As the result of the experimental study, it can be assumed that the use of authentic reading texts can help improve the reading comprehension abilities of some Pakistani students, especially the high achievers and the average learners studying in private sector schools. Keeping these findings in mind, it is suggested that second language programmes should incorporate authentic reading material at least to some extent.

Admittedly, since language learning is a multifaceted process, it is not possible to reach decisive conclusions from any applied linguistics-based research. However, at the same time, it is proposed that linguists should move beyond redefining the concept of authenticity and instead focus on investigating effects of authentic texts on diverse levels and types of second language learners in different countries and to conduct research highlighting the ways these texts can be effectively utilized in the classrooms. Presumably, experimental design with a longer treatment periods should be utilized in these research projects. Such empirical studies may provide more conclusive evidence which may lead to improvements in reading programmes the world over and benefit language learners.

\section{Author Note}

Asma Aftab, English Language Teaching Department, Kinnaird College for Women, Lahore, Pakistan; Afsheen Salahuddin, English Language Teaching Department, Kinnaird College for Women, Lahore, Pakistan.

Asma Aftab has done her PhD in Applied English Linguistics from University of Birmingham, UK. At present she is working as the co-ordinator of the English Language Teaching department at Kinnaird College for Women, Lahore, Pakistan.

Afsheen Salahuddin is working towards a PhD in Education at Lahore College University, Lahore, Pakistan. She did her M Phil in English Language Teaching from Kinnaird College.

Correspondence concerning this article should be addressed to Asma Aftab, Department of English Language Teaching, Kinnaird College for Women, 93, Jail Road, Lahore 54000, Pakistan. E-mail: drasmaaft23@gmail.com 


\section{References}

Aftab, A. (2011). English language textbooks evaluation in Pakistan (Unpublished doctoral dissertation), University of Birmingham, Birmingham, UK.

Berardo, S. A. (2006). The use of authentic materials in the teaching of reading. The Reading Matrix, 6(2), 60-69. Retrieved from http://www.readingmatrix.com/articles/berardo/article.pdf

Dörnyei, Z. (2007). Research methods in applied linguistics. Oxford, England: Oxford University Press.

Grabe, W., \& Stoller, F. L. (2011). Teaching and researching reading (2nd ed.). New York, NY: Routledge.

Guariento, W. \& Morley, J. (2001). Text and task authenticity in the EFL classroom. ELT Journal, 55(4), 347-353. http://dx.doi.org/10.1093/elt/55.4.347

Guo, S. C. (2012). Using authentic materials for extensive reading to promote English proficiency. ELT Journal, 5(8), 7-21. http://dx.doi.org/10.5539/elt.v5n8p196

Howe, D. H. (2007). Guided Eng/ish for Pakistan (Book 0). Karachi, Pakistan: Oxford University Press.

Ihtiari, K. B., Sundari, S., \& Andayani, M. A. (2013). The effect of using English authentic reading materials on the eighth grade students' reading comprehension achievement at SMP Negeri 1 Tempurejo. Pancaran, 2(2), 85-98. Retrieved from http://jurnal.unej.ac.id/index.php/pancaran/article/download/685/503

Iwai, Y. (2010). Re-envisioning reading comprehension for English language learners. The Internet TESL Journal, $X V \wedge 4$ ), Retrieved from http://iteslj.org/Articles/lwai-Reading.html

Jones, H., \& Mann, R. (2006). Step ahead 1. Singapore: Panpac Education.

Joy, J. J. L. (2011). The duality of authenticity in ELT. The Journal of Language and Linguistic Studies, 72), 7-23. Retrieved from http://www.jlls.org/index.php/jlls/article/viewFile/111/111

Konstantinos, D., \& Jeppe, J. L. (2005). Authentic texts or adapted texts - That is the question! Retrieved from http://dspace.mah.se/bitstream/handle/2043/1964/authenticandadapted.pdf

Mackey, A., \& Gass, S. M. (2005). Second language research: Methodology and design. Abingdon, England: Routledge.

Marzban, A., \& Davaji, S. (2015). The effect of authentic texts on motivation and reading comprehension of EFL students at intermediate level of proficiency. Theory and Practice in Language Studies, 5(1), 85-91. http://dx.doi.org/10.17507/tpls.0501.11

Mishan, F. (2004). Designing authenticity into language learning materials. Bristol, England: Intellect.

Morrow, K. (1977). Authentic texts and ESP. In S. Holden (Ed.), English for specific purposes (pp. 13-16). London, England: Modern English Publications.

Pinon, R., \& Haydon, J. (2010). English language quantitative indicators: Cameroon, Nigeria, Rwanda, Bangladesh and Pakistan. Retrieved from http://www.teachingenglish.org.uk/sites/teacheng/files/Euromonitor\%20Report\%20A4.p $\mathrm{df}$

Shomoossi, N., \& Ketabi, S. (2007). A critical look at the concept of authenticity. Electronic Journal of Foreign Language Teaching, 4(1), 149-155. Retrieved from http://eflt.nus.edu.sg/v4n12007/shomoossi.pdf

Snow, C. E., \& Sweet, A. P. (2003). Reading for comprehension. In A. P. Sweet \& C. E. Snow (Eds.), Rethinking reading comprehension (pp. 1-11). New York, NY: Guilford Press.

Tamo, D. (2009). The use of authentic materials in classrooms. Linguistic and Communicative Performance Journal, 2(1), 74-78. Retrieved from http://www.lcpj.pro/skedaret/1277547685-74_pdfsam_LCPJ,\%20Per\%20shtyp.pdf

Thornbury, S. (2006). An A-Z of ELT. Oxford, England: Macmillan Education. 
Tomlinson, B. (2008). English language learning materials: A critical review. London, England: Continuum. 